\title{
IDENTIFICANDO ALTAS HABILIDADES/SUPERDOTAÇÃO
}

Eduardo José MANZINI ${ }^{1}$

FREITAS, Soraia Napoleão; PÉREZ, Susana Graciela Pérez B. Altas habilidades/ superdotação: atendimento especializado. Marília: ABPEE, 2010, 118p.

Recentemente lançado pela editora da Associação Brasileira de Pesquisadores em Educação Especial ${ }^{2}$, o livro Altas habilidades/superdotação: atendimento especializado vem preencher uma lacuna na formação do professor. $\mathrm{O}$ ponto mais importante do livro é a riqueza de conteúdo referente a instrumentos que podem ser facilmente utilizados pelo professor para identificar possíveis alunos com altas habilidades/superdotação.

As autoras, com vasta experiência sobre o tema, propuseram um livro que aborda quatro conteúdos sobre altas habilidades/superdotação: 1) a discussão do tema e sua relação com a inclusão; 2) definição e instrumentos que auxiliam o professor na identificação de pessoas com altas habilidades/superdotação; 3) modelos de atendimento para alunos com altas habilidades/superdotação; e 4) estudos de casos de pessoas adultas com altas habilidades/superdotação.

No primeiro capítulo, são apresentados referenciais teóricos e, principalmente, documentos da legislação educacional brasileira que indicam os esforços da Educação Especial para garantir, aos alunos com altas habilidades/ superdotação, recursos técnicos e financeiros destinados a educação.

O segundo capítulo é uma das jóias do livro. Inicialmente são apresentadas e discutidas as características de alunos com altas habilidades/superdotação. Essa conceituação é discutida de forma ampla. Após essa explanação, o capítulo apresenta vários anexos na forma de fichas e questionários que servem de instrumento para a identificação de alunos com altas habilidades/superdotação. Esses instrumentos são destinados ao preenchimento por pais, professores e colegas de classe. Principalmente em relação aos professores, os questionários são divididos por série nas quais se encontram os alunos matriculados. O texto apresenta parte destes instrumentos preenchidos, discutindo dos dados encontrados.

\footnotetext{
${ }^{1}$ Docente do Departamento de Educação Especial e do Programa de Pós-Graduação em Educação da Unesp, Marília.

${ }^{2}$ Site da editora: www.abpee.net
} 
O terceiro capítulo discute e apresenta modelos de atendimento especializado para alunos com altas habilidades/superdotação. Nele, são tratadas questões como enriquecimento curricular e extracurricular, adaptação curricular, estratégias pedagógicas a serem desenvolvidas, dentre outros temas.

O quarto capítulo, também bastante inédito, trata do tema altas habilidades / superdotação em pessoas adultas. O texto traz um estudo de caso de várias pessoas adultas que são entrevistadas. Os relatos proporcionam identificar as várias características de pessoas com altas habilidades/superdotação discutidas no segundo capítulo do livro.

Como comenta Maria Helena Novaes Mira, na apresentação do livro:

Em suma, trata-se de contribuição relevante e atualizada que pode alavancar a motivação da sociedade brasileira por um atendimento adequado e urgente a essa população que merece uma atenção especial de todos (p.1). 